\title{
A Study on Retired Athletes’ Security Policy Optimization Based on the Capability
}

\author{
Dexin Zou ${ }^{1,2, *}$, Haochen Zou ${ }^{3}$ and Jian $\mathrm{Liu}^{4}$ \\ ${ }^{1}$ Sport Education Department, Nanjing Sport Institute, Nanjing, Jiangsu, China \\ ${ }^{2}$ Economics Development Center, Shenyang Sport University, Shenyang, Liaoning, China \\ ${ }^{3}$ Academy of computer science and technology, Shenyang Jianzhu University, Shenyang, Liaoning, China \\ ${ }^{4}$ Sports College, Nantong University, Nantong, Jiangsu, China \\ ${ }^{*}$ Corresponding author
}

\begin{abstract}
Based on the research data of Liaoning province and constructing logistic econometric model, it studies the influencing factors of retried athletes' life satisfaction with Amartya.Sen' capability theory. The result shows that five instrumental freedoms have great impact on retired athletes' life satisfaction, including rights security, political freedom, economic situation, social mechanism, transparency assurance, protective security. It puts forwards suggestions: optimizing the retired athletes' security policy, building up security policy idea based on capability and focusing on the athletes' development; setting up available right expressing channels to ensure retired athletes' rights; perfecting retirement compensation mechanism and building up retired athletes' economy foundation; improving human capital investment and accumulation to provide more chances for retired athletes; developing the supportive function to achieve maximum effectiveness of help resources; perfecting social security system and enhancing retired athletes' protective security.
\end{abstract}

Keywords—athletes; capability; logistic model

\section{INTRODUCTION}

In China, professional athletes devote a lot to national sports development. In 2008 Beijing Olympic Games, they won 100 medals, heading the medal table. All that set up a brand new sport imagery in the world. However, as a special group, athletes' career is limited. After retirement, they have a single choice for their professions, which will not defend the social risks. Although there are series of policies, it cannot meet the needs or solve the problems, such as athletes' education, employment, security and so on. Because a number of athletes retire every year and the enforcement of settlement policy is limited. All these challenge the nation in the process of transformation. Therefore, it is urgent to enhance the athletes' capabilities and solve the retired athletes' career development and long-term livelihoods[1-3].

\section{THE THEORY ANALYSIS}

In 1990s, welfare economist Amartya.Sen (Sen, 1992) suggested that welfare could not only be measured on material, but also on the immaterial substance. He proposed the theory of capability and approach, which is about individual welfare evaluation and development situation. Capability is the collection of possible multifunctional activities. However, the individual capability depends on five instrumental freedoms: political freedom, economic situation, social opportunity, transparency security and protective security. Political freedom refers to political participation, self-benefit expression and freedom; economic situation refers to the opportunity of having and using the economy resources; social opportunity is the system of education and health care, which affects the individual freedom of sharing life; transparency security refers to the information transparency, which is the foundation of the dealing with issues. Protective security is the social safety web for vulnerable groups. The five instrumental freedoms transform into capability influenced by personal characteristics, individual differences and external elements. To obtain capability not only sets an important goal for evaluating individual development, but also becomes the core security for realizing development.

Amartya.Sen' capability theory and approach provides a new perspective for analyzing vulnerable groups' poverty problem, improving this groups' far development and security policy. Based on Amartya. Sen's capability theory and retire athletes' characteristics, the paper constructs the retired athletes capability analysis structure. The retired athletes' capability depends on political freedom, economic freedom, social opportunity, transparency security and protective security. Political freedom refers to retired athletes' rights security, including rights expressing channel and rights expressing ability; economic situation includes financial compensation and income; social opportunity includes education, professional development training, physical and psychological health, family relationship web and information channel; transparency security includes the concern from society to retired athletes and the knowledge about the policies; protective security includes retired athletes' settlement and social security participation[4-5].

Retired athletes' capability analysis structure has advantages: first, it focuses on the origin of retired athletes' weakness and poverty, which means freedom lack and capability shortness. It seizes the essence of the retired athletes' security. Second, it can improve the efficiency. From the perspective of the instrumental freedoms realization, it can solve the retired athletes' security with a definite propose. Adopting retired athletes' capability analysis structure and survey data, this paper analyzes retired athletes' life optimization policy[6-7].

\section{Model Structure And Data Resource}

According to Sen' capability theory, capability is the crucial standard of evaluating welfare level and its development situation. The five instrumental freedoms: political freedom, economic situation, social opportunity 
transparency security and protective security are the significant elements for capability. Provided that the athlete is an economic man, he can judge the life reasonably. At the same time, it supposes that retired athletes' characteristics, rights security, economic situation, social opportunity, transparency security, protective security have great influence on life satisfaction. Setting up an empirical model about retired athletes' life satisfaction:

Retired athletes' life situation $=\boldsymbol{f}$ (personal characteristics, political freedom, economic situation, social opportunity, transparency security and protective security).

In the paper, the explained variable 'retired athletes' life is dichotomous variable. The athletes need to choose one item, 'satisfaction' or 'dissatisfaction'. 'Satisfaction' is defined as $\boldsymbol{y}=1$, 'dissatisfaction' is defined as $\boldsymbol{y}=0$, the probability is $\boldsymbol{y}=1, \boldsymbol{y}$ function is:

$$
f(y)=p^{y}(1-p)^{1-y} ; y=0,1
$$

The probability $\boldsymbol{P}$ is depended on athletes' instrumental freedoms, probability function obeys cumulative logistic probability function. Therefore, it uses binary Logistic probability model to evaluate the retired athletes' satisfaction with the life, as following:

$$
\begin{aligned}
& \boldsymbol{p}_{\boldsymbol{i}}(\boldsymbol{y}=1)=\frac{\boldsymbol{e}^{\beta_{0}+\beta_{1} x_{i 1}+\ldots . .+\beta_{n} x_{i n}}}{1+\boldsymbol{e}^{\beta_{0}+\beta_{1} x_{i 1}+\ldots . .+\beta_{n} x_{i n}}} \\
& \boldsymbol{p}_{i}(\boldsymbol{y}=1)=\frac{1}{1+\boldsymbol{e}^{-\left(\beta_{0}+\beta_{1} x_{i 1}+\ldots . .+\beta_{n} x_{i n}\right)}} \\
& =\frac{1}{1+\boldsymbol{e}^{-\beta_{0}-\sum_{j=1}^{n} \beta_{j} x_{i j}}}
\end{aligned}
$$

With Logistic transformation, it can linearize as following:

$$
\begin{aligned}
& \log \boldsymbol{i t}\left(\boldsymbol{P}_{\boldsymbol{i}}\right)=\ln \left(\frac{\boldsymbol{p}}{1-\boldsymbol{p}}\right)=\ln \boldsymbol{p}-\ln (1-\boldsymbol{p}) \\
& =\beta_{0}+\beta_{1} \boldsymbol{x}_{i 1}+\ldots \ldots+\beta_{n} \boldsymbol{x}_{i n}
\end{aligned}
$$

$\boldsymbol{p}_{\boldsymbol{i}}$ stands for the probability of the $i$ retired athlete' $\mathrm{s}$ satisfaction with life, the sample $\boldsymbol{i}=1,2 \cdots 176 ; \beta_{\boldsymbol{j}}$ stands for $\boldsymbol{j}$ the influencing factor of regression coefficient; $\boldsymbol{x}_{i j}$ represents the influencing factor of sample $\boldsymbol{i}$, which includes the variables, such as education level, benefits demanding channel, interest express ability, retirement settlement allowance, the standard of

\begin{tabular}{|c|c|c|c|c|c|}
\hline $\begin{array}{l}\text { Variable } \\
\text { Type }\end{array}$ & \multicolumn{2}{|c|}{ Variable } & $\begin{array}{l}\text { Vari } \\
\text { able } \\
\text { code }\end{array}$ & Evaluation & \multirow[b]{2}{*}{$\begin{array}{c}\text { Expe } \\
\text { ctati } \\
\text { on }\end{array}$} \\
\hline $\begin{array}{l}\text { Explaine } \\
\text { d variable }\end{array}$ & \multicolumn{2}{|c|}{$\begin{array}{l}\text { Retired athletes' life } \\
\text { condition }\end{array}$} & $\mathrm{Y}$ & $\begin{array}{c}1=\text { very } \\
\text { satisfied, } \\
\text { rather satisfied, } \\
\text { satisfied } \\
0=\text { dissatisfied, } \\
\text { rather } \\
\text { dissatisfied } \\
\end{array}$ & \\
\hline \multirow{17}{*}{$\begin{array}{l}\text { Explanat } \\
\text { ory } \\
\text { variable }\end{array}$} & \multirow{3}{*}{$\begin{array}{l}\text { characteri } \\
\text { stics }\end{array}$} & health & $\mathrm{X}_{1}$ & \multirow{3}{*}{$\begin{array}{c}\text { 1=excellent; } \\
\text { 2=better; } \\
\text { 3=good; } \\
\text { 4=worse; } \\
\text { 5=the worst }\end{array}$} & \\
\hline & & psychology & $\mathrm{X}_{3}$ & & \\
\hline & & $\begin{array}{l}\text { Vocation } \\
\text { plan }\end{array}$ & $\mathrm{X}_{3}$ & & \\
\hline & \multirow{2}{*}{$\begin{array}{l}\text { Rights } \\
\text { security }\end{array}$} & $\begin{array}{c}\text { Rights } \\
\text { expressing } \\
\text { channel }\end{array}$ & $\mathrm{X}_{4}$ & \multirow{2}{*}{$\begin{array}{c}\text { 1=excellent; } \\
\text { 2=better; } \\
\text { 3=good; } \\
\text { 4=worse; } \\
\text { 5=the worst }\end{array}$} & + \\
\hline & & $\begin{array}{c}\text { Rights } \\
\text { expressing } \\
\text { ability }\end{array}$ & $\mathrm{X}_{5}$ & & + \\
\hline & \multirow{3}{*}{$\begin{array}{l}\text { Economic } \\
\text { situation }\end{array}$} & $\begin{array}{l}\text { Retirement } \\
\text { settlement } \\
\text { allowance }\end{array}$ & $\mathrm{X}_{6}$ & \multirow{3}{*}{$\begin{array}{c}\text { 1=excellent; } \\
\text { 2=better; } \\
\text { 3=good; } \\
\text { 4=worse; } \\
\text { 5=the worst }\end{array}$} & + \\
\hline & & $\begin{array}{c}\text { The } \\
\text { standard of } \\
\text { disability } \\
\text { benefits }\end{array}$ & $\mathrm{X}_{7}$ & & + \\
\hline & & Income & $\mathrm{X}_{8}$ & & $+/-$ \\
\hline & \multirow{5}{*}{$\begin{array}{c}\text { Social } \\
\text { opportunit } \\
y\end{array}$} & $\begin{array}{c}\text { The } \\
\text { influence of } \\
\text { training on } \\
\text { knowledge }\end{array}$ & $\mathrm{X}_{9}$ & \multirow{5}{*}{$\begin{array}{c}\text { 1=excellent; } \\
\text { 2=better; } \\
\text { 3=good; } \\
\text { 4=worse; } \\
\text { 5=the worst }\end{array}$} & - \\
\hline & & $\begin{array}{c}\text { The chance } \\
\text { of } \\
\text { vocational } \\
\text { training }\end{array}$ & $\mathrm{X}_{10}$ & & + \\
\hline & & $\begin{array}{c}\text { Further } \\
\text { study }\end{array}$ & $\mathrm{X}_{11}$ & & + \\
\hline & & $\begin{array}{c}\text { Family } \\
\text { relationship } \\
\text { web } \\
\text { influence } \\
\end{array}$ & $\mathrm{X}_{12}$ & & + \\
\hline & & $\begin{array}{c}\text { The channel } \\
\text { of searching } \\
\text { jobs }\end{array}$ & $\mathrm{X}_{13}$ & & $+/-$ \\
\hline & $\begin{array}{c}\text { Transpare } \\
\text { ncy } \\
\text { security }\end{array}$ & $\begin{array}{c}\text { The } \\
\text { knowledge } \\
\text { of relative } \\
\text { policies }\end{array}$ & $\mathrm{X}_{14}$ & $\begin{array}{c}\text { 1=excellent; } \\
\text { 2=better; } \\
\text { 3=good; } \\
\text { 4=worse; } \\
\text { 5=the worst }\end{array}$ & + \\
\hline & \multirow{3}{*}{$\begin{array}{l}\text { Protective } \\
\text { security }\end{array}$} & $\begin{array}{c}\text { Social } \\
\text { security }\end{array}$ & $\mathrm{X}_{15}$ & \multirow{3}{*}{$\begin{array}{c}\text { 1=excellent; } \\
\text { 2=better; } \\
\text { 3=good; } \\
\text { 4=worse; } \\
\text { 5=the worst }\end{array}$} & + \\
\hline & & $\begin{array}{c}\text { Social } \\
\text { security } \\
\text { cohesion }\end{array}$ & $\mathrm{X}_{16}$ & & + \\
\hline & & $\begin{array}{c}\text { Social } \\
\text { security } \\
\text { participation }\end{array}$ & $\mathrm{X}_{17}$ & & + \\
\hline
\end{tabular}
disability benefits, income, vocational skill training, further study, the knowledge of related policies, social security system, social security participation and so on. $\mathrm{n}$ stands for the number of the variable; $\beta_{0}$ is intercept(table I ).
TABLE I. VARIABLE, EVALUATION AND EXPECATION

The empirical analysis data is from the research of the retired athletes' lives in 2016, which is about the survey of the retired athletes in Liaoning province. There are 176 effective samples in the survey. From the perspective of gender, there are 82 men, taking up $46.6 \%$ and 94 women taking up 53.4\%. 
From the age angle, the age from 16 to 20 takes up $10.2 \%$, the age from 21 to 29 takes up $72.2 \%$ and the age above 30 years old take up $17.6 \%$; from the angle of birthplace, $58.0 \%$ of the retired athletes are born in the city, $42.0 \%$ are born in the country; from the perspective of education, the retired athletes with associate diploma, bachelor degree and above take up $83.5 \%$, those with high middle school or technical secondary school education take up $11.4 \%$ and those with middle school education or below take up 5.1\%; from the point of sports event, skill event is $68.2 \%$, physical activity is $30.7 \%$ and comprehensive sport event is $1.1 \%$; from the rank, international master athlete is $11.4 \%$, master athlete is $43.8 \%$, first-class athlete is $32.4 \%$, second-class athlete and below is $12.4 \%$; on the aspect of training period, most respondents' training period, ranging from 6 to 15 years, takes up 76.1\%; from the point of retirement length, retirement less than 1 year takes up $29.0 \%$, 1-3years length takes up $45.5 \%$, 3-5years length is $13.1 \%$, retirement above 5 years is $12.5 \%$; the research data reflects retired athletes characteristics which have some representations(table II ).

TABLE II. RETIRED ATHLETES CHARACTERISTICES (N=176)

\begin{tabular}{|c|c|c|c|}
\hline Variable & Item & $\begin{array}{l}\text { Frequency } \\
\text { (n) }\end{array}$ & $\begin{array}{l}\text { Percentage( } \\
\%)\end{array}$ \\
\hline \multirow{2}{*}{ Gender } & Male & 82 & 46.6 \\
\hline & Female & 94 & 53.4 \\
\hline \multirow{3}{*}{ Age } & $16-20$ & 18 & 10.2 \\
\hline & $21-29$ & 127 & 72.2 \\
\hline & Above 30 & 31 & 17.6 \\
\hline \multirow{2}{*}{ Birthplace } & City & 102 & 58.0 \\
\hline & Country & 74 & 42.0 \\
\hline \multirow{4}{*}{ Education } & Postgraduate & 8 & 4.50 \\
\hline & University or college & 139 & 79.0 \\
\hline & $\begin{array}{l}\text { High middle school } \\
\text { or technical } \\
\text { secondary school }\end{array}$ & 20 & 11.4 \\
\hline & $\begin{array}{l}\begin{array}{l}\text { Middle school or } \\
\text { below }\end{array} \\
\end{array}$ & 9 & 5.1 \\
\hline \multirow{4}{*}{ Rank } & $\begin{array}{l}\text { International master } \\
\text { athlete }\end{array}$ & 20 & 11.4 \\
\hline & Master athlete & 77 & 43.8 \\
\hline & First-class athlete & 57 & 32.4 \\
\hline & $\begin{array}{l}\text { Second-class athlete } \\
\text { and below }\end{array}$ & 22 & 12.4 \\
\hline \multirow{4}{*}{ Training period } & Less than 6year & 10 & 5.7 \\
\hline & 6-10 years & 79 & 44.9 \\
\hline & $11-15$ years & 55 & 31.2 \\
\hline & Above 15years & 32 & 18.2 \\
\hline \multirow{4}{*}{ Retired period } & Less than 1 year & 51 & 29.0 \\
\hline & $1-3$ years & 80 & 45.5 \\
\hline & 3-5 years & 23 & 13.1 \\
\hline & Above 5 years & 22 & 12.5 \\
\hline
\end{tabular}

\section{EMPIRICAL ANALYSIS}

By using SPSS19.0 software, the paper is to do Logistic regression analysis on the influencing factors of retired athletes' satisfaction with lives. It introduces explanatory variable to Logistic model, using maximum likelihood method to solve the parameters in the model, the result as follow (tableIII):

The regression coefficients of the independent variables in the model reach very significant levels. The expected results of model are good. The variables, including rights security, political freedom, economic situation, social opportunity, transparency security, protective security, affect the retired athletes' satisfaction with life significantly. On the aspect of rights security, rights expressing channel and rights expressing ability are related to retired athletes' capability, which have a great influence on capability; on the aspect of economy, retirement settlement allowance, disability benefits and income have great influence on retired athletes' capability; on the aspect of social opportunity, the influence of training on knowledge and retired athletes' capability have negative correlation, which means the more influence on knowledge, the less retired athletes' capability is. Further study, family relationship web influence and the channel of searching jobs have positive effect on retired athletes' capability; on the aspect of transparency security, the knowledge of relative policies has positive influence on retired athletes' capability. On the aspect of protective security, social security system, social security cohesion and social security participation have positive correlation with retired athletes' capability, which have great influence.

TABLE III. LOGISTIC MODEL REGRESSION ANALYSIS RESULTS

\begin{tabular}{|c|c|c|c|c|c|c|}
\hline \multicolumn{2}{|c|}{ Explanatory variable } & \multirow{2}{*}{$\begin{array}{c}\beta \\
2.563\end{array}$} & \multirow{2}{*}{$\begin{array}{c}S . E \\
0.226\end{array}$} & \multirow{2}{*}{$\begin{array}{l}\text { Wald } \\
38.80\end{array}$} & \multirow{2}{*}{$\begin{array}{c}P \\
0.000\end{array}$} & \multirow{2}{*}{$\begin{array}{l}\exp (B) \\
17.085\end{array}$} \\
\hline $\begin{array}{c}\text { Characteris } \\
\text { tics }\end{array}$ & Health & & & & & \\
\hline & Psychology & 2.568 & 0.233 & 30.00 & 0.000 & 13.871 \\
\hline \multirow[t]{2}{*}{$\begin{array}{l}\text { Rights } \\
\text { security }\end{array}$} & $\begin{array}{l}\text { Rights } \\
\text { expressing } \\
\text { channel }\end{array}$ & 2.246 & 0.486 & 27.45 & 0.000 & 11.027 \\
\hline & $\begin{array}{l}\text { Rights } \\
\text { expressing } \\
\text { ability }\end{array}$ & 2.154 & 0.379 & 37.67 & 0.000 & 12.158 \\
\hline \multirow[t]{4}{*}{$\begin{array}{l}\text { Economic } \\
\text { situation }\end{array}$} & $\begin{array}{l}\text { Retirement } \\
\text { settlement } \\
\text { allowance }\end{array}$ & 2.078 & 0.208 & 29.05 & 0.000 & 10.787 \\
\hline & $\begin{array}{l}\text { Disability } \\
\text { benefits }\end{array}$ & 2.349 & 0.178 & 26.58 & 0.000 & 12.314 \\
\hline & Income & 2.612 & 0.222 & 0.459 & 0.000 & 11.427 \\
\hline & $\begin{array}{l}\text { The influence } \\
\text { of training on } \\
\text { knowledge }\end{array}$ & -2.643 & 0.481 & 40.36 & 0.000 & 12.619 \\
\hline \multirow[t]{4}{*}{$\begin{array}{c}\text { Social } \\
\text { opportunity }\end{array}$} & $\begin{array}{l}\text { The chance of } \\
\text { vocational } \\
\text { training }\end{array}$ & 2.492 & 0.213 & 34.72 & 0.000 & 14.526 \\
\hline & Further study & 2.227 & 0.238 & 44.17 & 0.000 & 12.138 \\
\hline & $\begin{array}{c}\text { Family } \\
\text { relationship } \\
\text { web influence }\end{array}$ & 2.467 & 0.223 & 35.32 & 0.000 & 10.575 \\
\hline & $\begin{array}{l}\text { The channel } \\
\text { of searching } \\
\text { jobs }\end{array}$ & 2.736 & 0.226 & 0.478 & 0.034 & 0.823 \\
\hline $\begin{array}{l}\text { Transparen } \\
\text { cy security }\end{array}$ & $\begin{array}{l}\text { The } \\
\text { knowledge of } \\
\text { relative } \\
\text { policies }\end{array}$ & 2.397 & 0.214 & 0.038 & 0.027 & 10.111 \\
\hline \multirow[t]{4}{*}{$\begin{array}{c}\text { Protective } \\
\text { security }\end{array}$} & $\begin{array}{l}\text { Security } \\
\text { system }\end{array}$ & 2.442 & 0.264 & 45.85 & 0.000 & 18.780 \\
\hline & $\begin{array}{c}\text { Social } \\
\text { security } \\
\text { cohesion }\end{array}$ & 2.174 & 0.206 & 47.09 & 0.000 & 13.051 \\
\hline & $\begin{array}{c}\text { Social } \\
\text { security } \\
\text { participation }\end{array}$ & 2.265 & 0.214 & 38.32 & 0.000 & 17.064 \\
\hline & Constant & -7.754 & 2.431 & 30.11 & 0.000 & 12.334 \\
\hline \multicolumn{2}{|c|}{ Observation $\mathrm{N}$} & \multicolumn{5}{|c|}{176} \\
\hline \multicolumn{2}{|c|}{$\begin{array}{l}\text { Likelihood ratio test } \\
\text { (Chi-square) }\end{array}$} & \multicolumn{5}{|c|}{47.460} \\
\hline \multicolumn{2}{|c|}{$\begin{array}{l}\text { Test of goodness of fit } \\
\text { (-2Loglikelihood) }\end{array}$} & \multicolumn{5}{|c|}{98.111} \\
\hline \multicolumn{2}{|c|}{ NagelkerkeR square } & \multicolumn{5}{|c|}{0.579} \\
\hline
\end{tabular}




\section{CONCLusion AND SugGestion}

It proves that retired athletes' rights and benefits security, political freedom, economic situation, social opportunity, transparency security and protective security have great influence on retired athletes' capability. According to the results, it puts forward the suggestions on retired athletes' security policy.

\section{A. Setting up Security Policy Based on Capability, Focusing on Athletes' Further Development}

It should set up the idea of improving retired athletes' capability security policy, seeing developing capability as the basic aim and insisting on humanistic concern, sustainable livelihood, to realize the combination of sports and athletes' development, short-term currency compensation and capability boosting, security system and individual response, protecting the long-term effect of retired athletes related policies with various livelihood to boost retired athletes' further development.

\section{B. Building up Rights and Benefits Express Channel and Protecting Retired Athletes Rights}

First, the departments should make the group of the retired athletes have their function, improve the rationality of policy and decrease the infringement; Second, it should enhance the law construction to protect retired athletes' rights and transparency security implement; Third, legal aid should be provided to express individual rights and benefits; information platform, as a channel, needed to be set up to get the information and do communication, which is helpful to enhance the motivation of the policy implement observation and the transparency of the policy implement.

\section{Perfecting Retired Compensation Mechanism, Building up Retired Athletes' Economic Foundation}

It should be focused on developing retired athletes' capability and building up economy foundation. There are some problems in retired athletes' compensation mechanism, such as the standard is low, the items are not reasonable. The retirement compensation should adjust to the economy development level; the compensation should be increased for the weight lifting athletes due to the low marketability. In order to keep fair, appropriate compensation should be given to some athletes at the bottom of pyramid.

\section{Improving Human Capital Investment and Accumulation and Providing More Social Opportunities for Retired Athletes}

People should help retired athletes make career development plan and grasp the professional training chance; setting up a right career viewpoint, changing the phenomena "without talking about the retirement on training", leading athletes to emphasize education, professional quality and skills to set a good foundation for retirement; providing suitable training service for different stages of professional transformation and adjusting the training methods and contents to encourage retired athletes to career transition, ensure the retired athletes have sustainable development ability and provide more social opportunities.

\section{E. Developing Social Support and Maximizing the Utility of Support-resources}

It is essential to build up a mechanism including government, welfare organization and enterprises and enlarge the cooperation between government and non-government organizations. By using the advantage of non-government organizations, it is going to complement the following aspects, such as social mobilization, training, employment and research on need. Encouraging enterprises to employ retired athletes to achieve win-win is necessary. Management organizations, nongovernment organizations and research institutions should combine the resources to set up a platform to provide retired athletes' employment, professional training and service. In this way, it can help retired athletes perform potentials and provide the correct information on government making decisions and enterprises employing retired athletes.

\section{F. Developing Social Support and Maximizing the Utility of Support-resources}

It is essential to build up a mechanism including government, welfare organization and enterprises and enlarge the cooperation between government and non-government organizations. By using the advantage of non-government organizations, it is going to complement the following aspects, such as social mobilization, training, employment and research on need. It also needs to guide the enterprises to treat retired athletes properly and realize their professional value. Encouraging enterprises to employ retired athletes to achieve win-win is necessary. Management organizations, nongovernment organizations and research institutions should combine the resources to set up a platform to provide retired athletes' employment, professional training and service.

\section{G. Perfecting Social Security System and Enhancing Retired Athletes' Protective Security}

The perfect social security system is the significant security for retired athletes, a special group. Retired athletes' endowment insurance should be distributed into urban endowment insurance to make retired athletes own the social endowment insurance standard which is suitable for the economy development; encouraging some athletes to buy commercial assurance. Helping those who have serious injuries or no work ability get unemployment insurance; helping those who have economy or employment problems achieve the basic life security. The government should set the special foundation to attend to the retired athletes with great contribution and life difficulties. The foundation represents humanistic care. It is necessary to enhance the scientific level of training system, decrease the injury and disability rate in training and competition.

\section{ACKNOWLEDGMENT}

This work is supported by Found projects: National Social Science Foundation (17BTY049); National Social Science Foundation (14BTY069). 


\section{REFERENCES}

[1] S. Amartya, Development of Freedom, Beijing: China Renmin University Press, 2002.

[2] M. John, Alexander, Capabilities and Social Justice: The Political Philosophy of Amartya Sen and Martha Nussbaum. London;New York: Rout-ledge, 2016.

[3] F. Magni, Metaethical Issues in the Capability Approach.The Fourth International Conference on the Capability Approach, 2004.

[4] I. Robeyns, The Capability Approach: a Theoretical Survey. Journal of Human Development, 2005, pp. 19-23.

[5] G.Solon, A model of intergenerational mobility variation over time and place. In:Corak, Miles(Ed.), Generational income mobility in North America and Europe Cambridge University Press,Cambridge,2004, pp. 38-47.

[6] F. M. Gong, S. H. Ma, Y. Tang, Empirical Study on the Influence between Logistics information Capabilities and Supply Chain Performance, Industrial Engineering and Management, 2007, pp. 12-18.

[7] H. Youn, Z. Gu, Predict US restaurant firm failures: The artificial neural network model versus logistic regression model. Tourism \& Hospitality Research, 2010, pp. 171-187. 